\title{
ON HIGH-FREQUENCY SEISMIC MOTIONS OF REINFORCED CONCRETE STRUCTURES
}

\author{
Masayasu OHTSU ${ }^{1}$ \\ ${ }^{1}$ Member of JSCE, Dr. of Eng., Professor, Dept. of Civil and Environmental Eng., Kumamoto University \\ (Kurokami 2-39-1, Kumamoto 860, Japan)
}

\begin{abstract}
In relation to disastrous damage of reinforced concrete $(\mathrm{RC})$ columns due to recent Hanshin-Awaji Earthquake, high-frequency behavior of RC beams subjected to impact loading is reexamined. Thus, the effect of high-frequency horizontal motions on the columns is inclusively studied, solving RC beams in the elastic range by.BEM. From the dimensional analysis, it is suggested that the local failure mode of the columns due to horizontal motions could result from high-frequency earthquakes over $10 \mathrm{~Hz}$. The stress analysis suggests spalling failure of cover concrete due to high-frequency bending motions and the high shear stress zone localized at one end due to the higher frequency motions.
\end{abstract}

Key Words : impact test, RC members, BEM analysis, dimensional analysis, high-frequency motion

\section{INTRODUCTION}

Recent Hanshin-Awaji Earthquake has brought tremendous disaster and damage on concrete structures ${ }^{1}$. As a result, numerous topical issues and urgent forums are offered by a variety of organizations, institutes and societies. One of unexpected disaster widely-reported is failure and damage of reinforced concrete (RC) columns. Some of critical phases on the failure are pointed out, as follow:

1) causal directions of vibration; horizontal or vertical,

2) failure modes resulted in disastrous failure; shear or bending, and

3) effect of high-frequency motions due to epicentral quake.

At present, answers and reasons on these findings are intensively studied by a number of research groups. Previously, dynamic behavior of RC beams due to impact was investigated in our lab., and some effects of high-frequency motions on the beams were clarified by the boundary element method (BEM) ${ }^{2}$. Reexamining these results and analyzing new models, the effect of high-frequency horizontal motions on the $\mathrm{RC}$ column is studied. The effect of high-frequency motions on $\mathrm{RC}$ members is not probably associated with ultimate failure, but could be referred to as triggering the nucleation of dynamic failure. Consequently, the analysis is conducted on RC beams in the elastic range. Although the boundary conditions of the columns are different from those of the beams, the basic relation between the resonance modes of high-frequency motions and the failure modes could be derived from the dimensional analysis. In order to clarify the stress generation under dynamic motions, the elastic stress analysis of RC beams due to high-frequency loads is also performed.

\section{DYNAMIC MOTIONS}

Dynamic elastic behavior of a RC member is mathematically represented by a function, $F(x, t)$ on the location vector, $x$ and time variable, $t$. Since a continuous function on $t$ can be. expanded into Fourier series, we have,

$$
\begin{aligned}
F(\boldsymbol{x}, t) & \left.=\Sigma\left[a_{n}(\boldsymbol{x}) \cos 2 \pi f_{n} t+b_{n}(\boldsymbol{x}) \sin 2 \pi f_{n} t\right)\right] \\
& =\Sigma c_{n}(\boldsymbol{x}) \exp \left(i 2 \pi f_{n} t\right) .
\end{aligned}
$$

Complex coefficient $c_{n}(\boldsymbol{x})$ at frequency $f_{n}$ can be obtained as solution $u_{i}(\boldsymbol{x})$ of Navier's equation in the steady state,

$$
(\lambda+\mu) u_{j, i j}(\boldsymbol{x})+\mu u_{i, j j}(\boldsymbol{x})+\left(2 \pi f_{n}\right)^{2} u_{i}(\boldsymbol{x})=0,
$$

where $\lambda$ and $\mu$ are Lame constants.

From eqs. 1 and 2 , it is realized that actual behavior of the structure could be reproduced as a linear combination of the motions $u_{i}(\boldsymbol{x})$ at particular frequency $f_{n}$. Thus, a key issue is the analysis of dynamic steady-motions due to particular frequency incidence. For this purpose, a BEM code for the two -dimensional (in-plane motion) elastodynamic steady -state problem is developed ${ }^{2}$. 

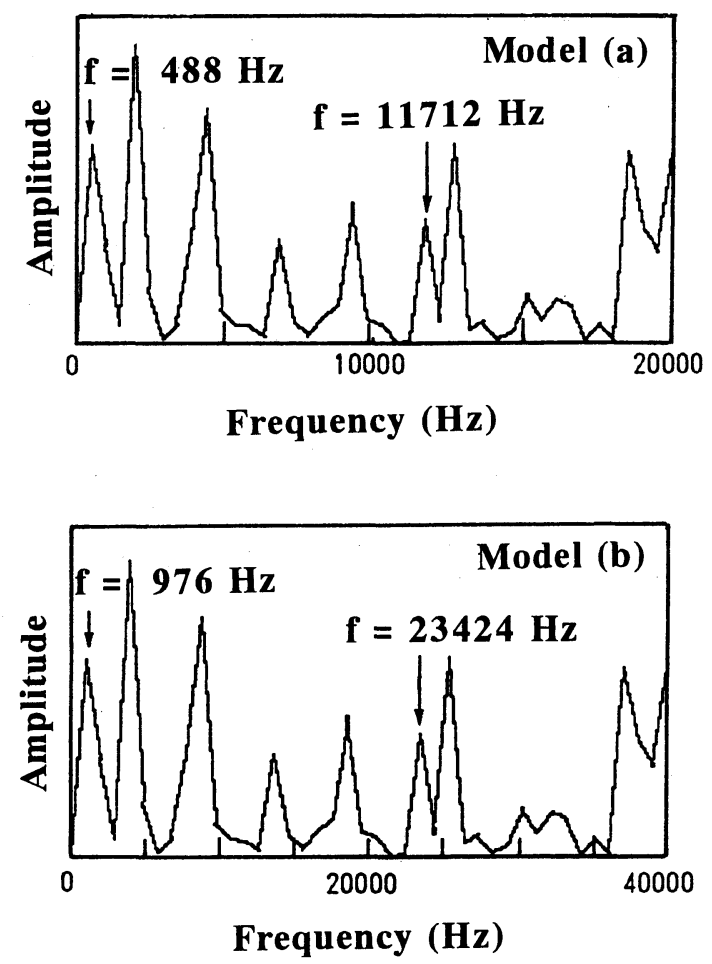

Fig. 1 Frequency responses of the two RC beams.

\section{DIMENSIONAL ANALYSIS}

Dynamic behavior of a structure is characterized by incident wave motions, material properties, and structure sizes. The kinetics of motions is prescribed by frequency $f$, or period $T$ which is equal to $1 / f$. The material property essentially responsible for dynamic motions is elastic-wave velocity $v$, which is derived from Young's modulus, Poisson's ratio, and the density. The effect of the kinetics and the wave velocity are united as wavelengths, $v / f$. Then, a relation between the wavelength and the structure sizes contributes to complicated dynamic behavior of the structure.

In the present case, the structure sizes to be taken into account are the length or span $L$, and the width or depth, $h$, of the member, which lead to a non -dimensional parameter; aspect ratio $\lambda$. Normalized parameter $x$ is assumed as the following function,

$$
x=F(f, v, L, \lambda) \text {. }
$$

The analysis leads to a relation,

$$
x=\lambda f L / v \text {. }
$$

This implies that the similar dynamic behavior is predicted in the case that parameters $x$ and $\lambda$ are identical.

The applicability of the relation is studied by analyzing dynamic responses of two similar RC beams.

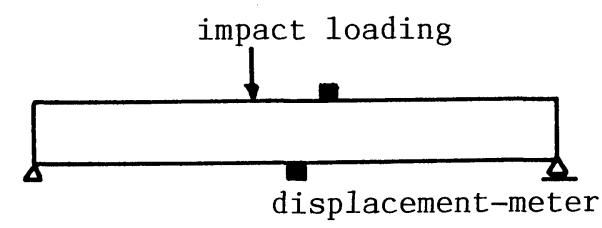

(1) Case $\kappa=0.878(\lambda=9)$

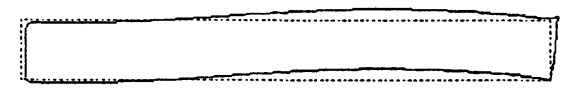

Model (a) at $488 \mathrm{~Hz}$

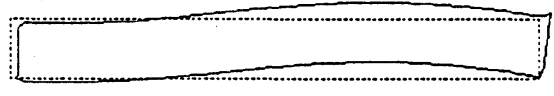

Model (b) at $976 \mathrm{~Hz}$

(2) Case $\kappa=21.08(\lambda=9)$

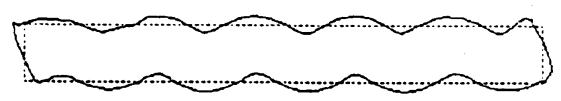

Model (a) at $11712 \mathrm{~Hz}$

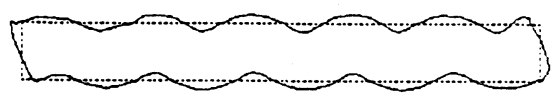

Model (b) at $23424 \mathrm{~Hz}$

Fig. 2 Resonance vibration modes at the two peak frequencies in Fig. 1.

These are model (a) of dimension $L=90 \mathrm{~cm}$ and $h=$ 10 and model (b) of dimension $45 \mathrm{~cm} \times 5 \mathrm{~cm}$. Both models are of the aspect ratio $\lambda=9$, and are loaded at $2 / 9$ of the span from the left edge. Vertical displacements on the top at $4 / 9$ of the span from the right edge are analyzed by BEM. Configuration of the specimen is given at the top of Fig. 2. In the analysis, equivalent Young's modulus to the RC beam is employed $^{2)}$. Young's modulus is $34.3 \mathrm{GPa}$, Poisson's ratio is 0.2 , and the density is $2300 \mathrm{~kg} / \mathrm{m}^{3}$. Responses due to impact with $488 \mathrm{~Hz}$ frequency increment are shown in Fig. 1. P wave velocity of the models $v_{p}$, is identical, because of the same material constants.

From eq. 4, input frequencies $f_{a}$ of model (a) and $f_{b}$ of model (b) are related as,

$$
\begin{aligned}
\chi & =9 f_{a}(0.9) / v_{p} \\
& =9 f_{b}(0.9) / v_{p} .
\end{aligned}
$$

And thus, $2 f_{a}=f_{b}$

The relation of eq. 5 clearly holds in Fig. 1. Vibration modes at the two peak frequencies in Fig. 1 are 
given in Fig. 2. In the model (a), the peak frequency $488 \mathrm{~Hz}$ corresponds to the case $x=0.878$, and $x=21.08$ at another peak frequency, $11712 \mathrm{~Hz}$. Between the models (a) and (b), the similarity on vibration modes is surely confirmed.

Corresponding to the case $x=0.878$, the similar resonance vibration of an actual structure is predicted at frequency $13.55 \mathrm{~Hz}$ for the case that the length $L$ $=18 \mathrm{~m}$, the width $h=2 \mathrm{~m}$, and P wave velocity $2500 \mathrm{~m} /$ $\mathrm{s}$. It is reported that many columns destructed in the earthquake are of around 10 to $20 \mathrm{~m}$ height. As can be seen in Fig. 2, in the case $x=0.878$, only $1 / 3$ right portion of the beam is dominantly deformed. It suggests the fact that the failure mode of the column corresponding to the resonance deformation given results from high-frequency components of earthquakes over $10 \mathrm{~Hz}$. In the case of stubby columns, the aspect ration $\lambda$ become smaller than those of slender columns. It suggests that the resonance frequency associated with the failure mode could become even higher.

Another suggestion is derived from eq. 4 in respect to hybrid seismic-loading tests ${ }^{3,4}$. In those experiments, seismic waves are often extended in the time scale. It leads to lower frequency. Since the structure sizes are also smaller in the model tests except for full -scale testing, the parameter $x$ becomes eventually small and the effect of high-frequency other than large deformation and cyclic loading may not be simulated.

\section{STRESS ANALYSIS}

To clarify the failure mechanisms and identify the locations of localized failure, the dynamic stress analysis is performed. RC beam of dimension $L=1.2 \mathrm{~m}$ and $h=0.06 \mathrm{~m}$ (aspect ratio: $\lambda=20$ ) is analyzed. One reinforcing bar is embedded at $3 \mathrm{~cm}$ cover thickness. In the experiments ${ }^{2}$, it was found that the first resonance of axial strain at the center-bottom is observed at $292 \mathrm{~Hz}$. Thus, an equivalent Young's modulus was determined as $35.6 \mathrm{GPa}$. Poisson's ratio was 0.2 , and the density was $2490 \mathrm{~kg} / \mathrm{m}^{3}$. Furthermore, the effect of reinforcement on dynamic behavior was studied in the experiment. It is realized that the difference between vibration motions of $\mathrm{RC}$ beams and those of plain concrete is inconsequential under global resonance modes.

Impact stress $1 \mathrm{MPa}$ of this frequency was applied to the beam. The corresponding stress distribution is given is Fig. 3. Negative values indicate compressive stresses. The normalized parameter $x=1.56$ for $292 \mathrm{~Hz}$.

As can be seen, the vibration mode and the stress distribution $\sigma_{x x}$ are of bending. In the central region,

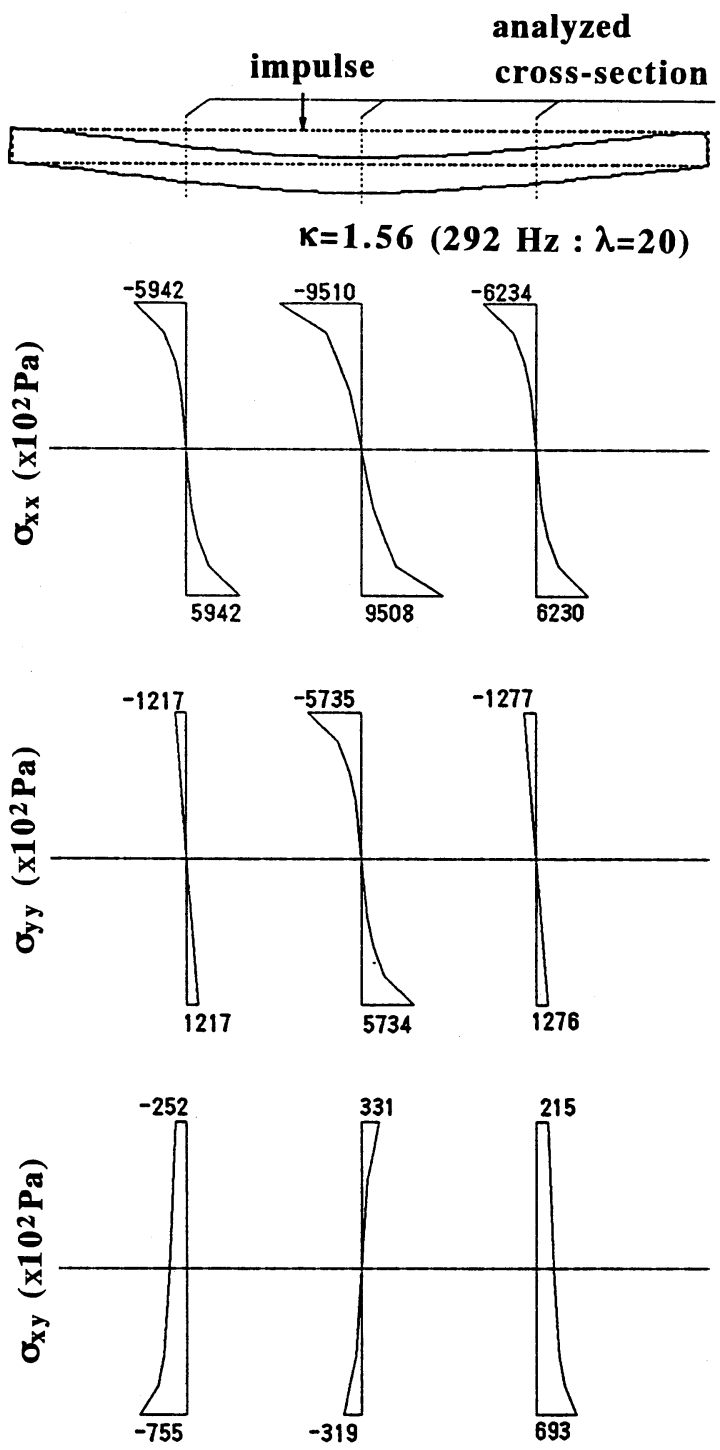

Fig. 3 Stress distribution in the beam at $292 \mathrm{~Hz}(x=1.56$ and $\lambda=20$ ).

large tensile stress $\sigma_{y y}$ almost half of the axial stress $\sigma_{x x}$ is observed.

Since the axial stress is reinforced in the $\mathrm{RC}$ beam, the large $\sigma_{y y}$ values suggest spalling of cover concrete. In the case that the column length $20 \mathrm{~m}$ and $\mathrm{P}$ wave velocity $=2500 \mathrm{~m} / \mathrm{s}$, an actual frequency corresponds to $9.75 \mathrm{~Hz}$. Thus, spalling of cover concrete is predicted due to high-frequency bending motions. It is noted that the ratio of the maximum shear stress to the maximum axial stress is just $8 \%$.

To study the stress distribution of a similar deformation to the case (1) $k=0.878$ in Fig. 2, the input frequency $500 \mathrm{~Hz}$ is applied to the model. The case corresponds to $x / \lambda=0.134$, which is fairly close to the 


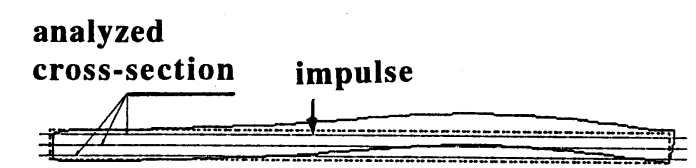

$\kappa=2.67(500 \mathrm{~Hz}: \lambda=20)$

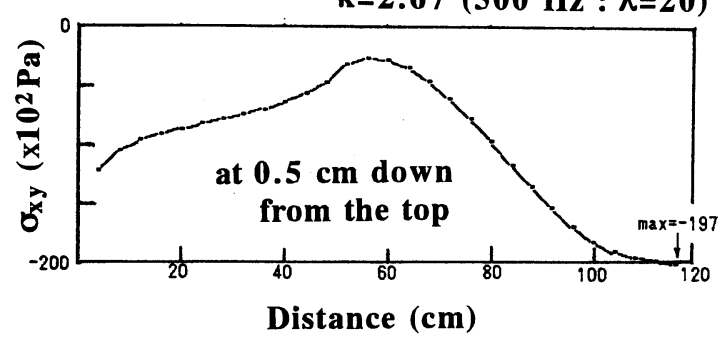

Fig. 4 Shear stress distribution at $500 \mathrm{~Hz}$.

case (1) in Fig. $2(x / \lambda=0.098)$. A result of shear stress distribution at the cross-section $0.5 \mathrm{~cm}$ down from the top surface is given in Fig. 4. In the analysis, it is found that the maximum axial stress $122 \mathrm{kPa}$. The maximum shear stress is observed $-19.7 \mathrm{kPa}$ at nearly the right end of the beam. Since the maximum axial stress was $122 \mathrm{kPa}$, the ratio of the maximum shear stress to the maximum axial could reach up to $16 \%$, which might be high enough for shear failure. Comparing Fig. 4 with Fig. 2, it is realized that the high shear stress zone is generated at the $1 / 3$ right portion of the beam. It implies that shear failure of the slender column could occur at this region due to high-frequency vibration. Although equivalent Young's modulus is assumed, this is not only the case of plain concrete but also corresponds to that of the $\mathrm{RC}$ beam under global resonance modes. the $\mathrm{RC}$ column is studied, solving analytically $\mathrm{RC}$ beams in the elastic range. The basic relation between the resonance modes of high-frequency motions and the failure modes is elucidated by the dimensional analysis and the elastic stress analysis.

(1) The results of the dimensional analysis suggest the fact that the local failure mode of the column due to horizontal vibration could result from high-frequency components of earthquakes over $10 \mathrm{~Hz}$.

(2) Spalling of cover concrete is predicted under high -frequency bending motion. Concerning the local failure mode, the high shear stress zone is identified at the $1 / 3$ right portion of the beam. The stress reaches almost $20 \%$ of the maximum axial stress, which may be high enough for shear failure at the end of the column.

\section{REFERENCES}

1) Nonaka, T., Miura, K. and Tanimura, S. : A Note on Structural Failure due to the Great Hanshin Earthquake, Materials Science Research International, Vol. 1, No. 2, pp.132-133, 1995.

2) Ohtsu, M. and Kaneda, K.: Dynamic Behavior of Reinforced Concrete Beams subjected to an Impact Test, Journal of Structures and materials in Civil Engineering, No. 11, pp.17-23, 1996.

3) Okada, T.: Simulation of Earthquake Response of Structures by Computer-Actuator On-Line System, Concrete Journal, Vol. 20, No. 1, pp.31-37, 1982.

4) Iemura, H.: Development and Future Prospect of Hybrid Experiments, Proc. JSCE, No. 356/1-3, pp.1-9, 1985.

(Received September 8, 1995)

\section{CONCLUSION}

The effect of high-frequency horizontal motions on

\section{鉄筋コンクリート構造物の地震時高周波数挙動について}

\section{大津 政康}

阪神・淡路大震災の災害報告により，鉄筋コンクリート（RC）構造物，特に，橋脚の破壊様式が問題となって いる.この原因究明にむけて様々な研究が進められているが，本研究ではこれまでに実施した (RC) 梁の衝撃試 験の結果に基づいて, RC 柱の横荷重に対する高周波数挙動の考察を試みたものである. 次元解析により, 無次元 パラメータの実用性を境界要素法のモデル解析により確認した。 そして, 実在構造物の場合に横振動による共振 周波数は $10 \mathrm{~Hz}$ 以上となることが認められた。さらに，応力解析により，高周波数応答時の曲げ振動による剥離 ひびわれの発生と高せん断応力領域の発生の可能性を明かにした。 